\title{
Self-Sufficient Revival of Recreational Garden in Affordable Housing Development
}

\author{
Sherebano Safdari ${ }^{1}$, Manoj Parelkar ${ }^{2}$, Roshni Udyavar Yehuda ${ }^{3}$ \\ ${ }^{1}$ Post graduate student, Masters in Architecture (Environmental), Rachana Sansad's Institute of Environmental Architecture, Mumbai \\ ${ }^{2}$ Professor, Rachana Sansad's Institute of Environmental Architecture, Mumbai \\ ${ }^{3}$ Head of Department, Rachana Sansad's Institute of Environmental Architecture, Mumbai
}

\begin{abstract}
Urbanization has resulted into shrinking of recreational open spaces to accommodate more infrastructure and development. And, to provide 'housing for all', affordable housing developments are being promoted. To utilize the land to its maximum, the authorities increase Floor Space Index and decrease the recreational open spaces in such type of housing development. The population living in such housing is not affluent enough to maintain and enhance this small piece of land given to them for recreation. The paper is an attempt to review the recreational spaces in affordable housing with Mumbai as a context, and cost and maintenance as a parameter for its sustenance.
\end{abstract}

Keywords: Recreational garden, affordable housing, self-sufficient garden design

\section{Introduction}

The place where a man lives determines the quality of life he has. The open recreational spaces are an important part of the place which enriches the quality of life people around it. These open recreational spaces provide physical and social satisfaction to the inhabitants. As Kent (2015) rightly said that the purpose of an open space in a settlement is to provide standard recreational activities, maintenance of parks in conjunction with development so as to protect health, safety, and general welfare of the people, improves quality of life and the appearance of the community. [11]

\section{Recreational Open Space}

As per the definition by Merriam-Webster, recreation is 'refreshment of strength and spirits after work' [13]. Hence, Recreational open spaces provide people with the opportunities to do passive recreational pursuits such as walking, sitting, chatting and general relaxing, and also active recreational activities like active games and exercising. As described by Kakkar (2014), the main types of recreational spaces are as follows:

- Parks

- Linear Open Spaces

- Amenity space within housing areas

- Natural/informal open spaces

- Ornamental gardens

- Grassed sitting lawns

\subsection{Benefits of Recreational Open Spaces}

As per IFPRA (International Federation of Parks and Recreation Administration), the potential benefits of recreational open spaces are:

1) Human health and wellbeing both mental and physical through recreation and leisure activities.

2) It also strengthens local cohesion amongst communities and helps build social identity.
3) A recreational open space also helps flourish biodiversity in the vicinity and provides people with natural experiences of sighting the biodiversity.

4) Another very important benefit in context to urban communities is the maintenance of good air quality and carbon sequestration.

5) Also, these spaces can help in water management $\&$ storm water run-off. Many researchers have also investigated and concluded that such spaces provide cooling to urban areas. [3]

As per the Millennium Ecosystem Assessment, the first two benefits stated above fall under the group 'cultural ecosystem services' and the latter three benefits come under 'regulating ecosystem services' [12].

\section{Recreational Space in India}

In India, while preparing a Master Plan or Development Plan, a detailed analysis of the existing land use pattern is carried out. A land use plan is formulated after considering the projected population and broad land uses in an area. Green areas are normally classified for recreational use. As per UDPFI guidelines, 1996 Ministry of Urban Development, the proportion of recreational areas to the total developed areas should be $20-25 \%$ in metropolitan cities. Generally, areas under parks, botanical gardens, water bodies, and playground are classified under recreational use. [19]

The types of open green spaces in settlements in India are classified as follows:

1. Reserved Forest

2. Protected Forest

3. National Park

4. District Park

5. Neighborhood Park

6. Children's Play Area

7. Playground

8. Green Belt 


\section{International Journal of Science and Research (IJSR) \\ ISSN (Online): 2319-7064}

Index Copernicus Value (2015): 78.96 | Impact Factor (2015): 6.391

\section{Recreational space in context to Mumbai}

As per the Census Commission of India, the urban population has grown five times in fifty years. Mumbai which has seen a rapid urban growth was included in the United Nations list of 31 megacities, which have to check their trends in urbanization as they are crucial to the implementation of the Agenda for Sustainable Development 2030.'[18]. One of the major trends of the urbanization in Mumbai is reduction of per capita open green space.

According to World Health Organization (WHO), the minimum standard availability of open green space per city dweller is 9 sq.mtrs [19]. Mumbai has just 1.58 sq.mtrs of open green space per person [4]. Comparatively, New Delhi has a far better ratio of of 22 sq.m[19]. Hence, the development policies in Mumbai have to be drafted so as to strive for a better ratio of open green space per city dweller in the coming years.

As per the Development Plan 2034 of Mumbai, few land parcels of salt pan lands and Coastal Regulation Zone (CRZ) area will be unlocked for development. Due to these current development policies in Mumbai, there is a threat that the ratio of open green space per capita will further reduce to 0.87 sq.mtrs. [4]. Hence, there is an urgent need to safeguard and revive its green space through parks and gardens.

\subsection{Development Control Regulation for Recreational Ground (RG)}

In an effort to maintain the ratio of open green space per capita in cities, development regulation has stated that a certain portion of all plot and layout development has to be recreational ground (RG). The Recreational Grounds (RG) of layout developments is not accessed by the general public and can be termed as 'community recreation space'. They are meant exclusively for the recreational needs of the residents of that development. Layout Recreational Grounds (RG) provides space for children to play and adults to socialize with neighbors. Layout RGs are not acquired by Bombay Municipal Corporation (BMC) and are generally maintained by housing societies with their maintenance funds. The Development Control Rules-2016 required Recreational Ground (RG) on Layout plot in Mumbai are as follows:

1) Plot Area 1000 to 2500 sq.mtrs - required Recreational Ground (RG) is $15 \%$

2) Plot Area 2500 to 10000 sq.mtrs- required Recreational Ground (RG) is $20 \%$

3) Plot Area over 10000 sq.mtrs- required Recreational Ground (RG) is $25 \%$.

4) In an affordable housing development, a plot layout admeasuring 4000 sq.mtrs or more after deducting D.P.road and reservation area, if any, $10 \%$ of the entire holding area shall be reserved as recreational open space which shall as far as possible be provided in one place. [17]

\subsubsection{Recreational Ground (RG) in Affordable Housing Development}

The Recreational Ground (RG) in an affordable housing is only $10 \%$ of the plot area as compared to the other housing developments which has $25 \%$ of the plot area as
Recreational Ground. The less percentage of RG in affordable housing development is to accommodate high population density and carve out maximum number of dwelling units for lower income (LIG) and middle income groups (MIG). This strategy of providing only a $10 \% \mathrm{RG}$ to such development creates tremendous pressure on the recreational space. On the other hand, the less availability of recreational space makes it very precious. Unlike the land developers, the people of such affordable housing are not very affluent to contribute a huge amount of money to maintain this recreational space. Hence, the recreational ground remains less maintained, dilapidated, or is encroached upon. Due to the fund crunch and scarcity of space, there is a gap in the maintenance and resilience of such recreational spaces. To preserve this space, a self sufficient revival model of recreational space has to be developed.

The gap can be further consolidated with the studies done by Cohan, who found out that recreational spaces in lowincome neighborhood is less used than the high-income neighborhoods due to less maintenance, greenery and facilities. She also concluded in her study that offering programmed efforts, enhancing walking loops and population specific installations and facilities may attract more users [6].

\section{Revival Model}

\subsection{Need of the population}

The American Society of Landscape Architects (ASLA) rightly states that recreational space design needs to be compelling so that 'people visit and forge community ties there. These spaces that are designed for local residents and include them in the process often do the best.' [2]. Similar thoughts are echoed by Das, as he states that each community has different needs, demands and aspirations and to address this diversity also enables people's active participation in revivals.[5]

Hence, the study of needs, demands and aspirations of the population for revival model of the recreational garden is very essential.

RAND is a nonprofit research organization providing objective analysis and effective solutions that address the challenges facing the public and private sectors around the world. This organization conducted a research on 'Park use and Physical Activity in a Sample of Public park in the City of Los Angeles' in the year 2006. For the analysis of needs and physical activity of the population in a park, the organization developed a tool called as SOPARC (Systematic Observation of Play and Recreation in Communities) which consisted of a systematic observation form and questionnaire for the users of the park about their perception and aspirations [16].

This SOPARC tool has been used by many researchers to assess the needs of the park users. Researchers have also modified the tool to help them analyze the target communities for their research questions. The SOPARC tool 


\section{International Journal of Science and Research (IJSR) \\ ISSN (Online): 2319-7064}

Index Copernicus Value (2015): 78.96 | Impact Factor (2015): 6.391

can be taken as a standardized model to evaluate the needs of the population.

\subsection{Strategies for the Self Sufficient Revival of Recreation Garden}

The strategies that can be adopted for self-sufficiency in recreational garden so that they become low maintenance and cost effective, in context to the affordable housing development can be through Material conservation, Water conservation, sustainable landscape practices and solid waste composting and recycling.

\subsubsection{Material Conservation}

According to American Society of Landscape Architects, a new park can be created out of old building materials. Reclaimed soils, concrete rubble, glass, wood, and steel can be reused or recycled to serve new functions in a recreational garden design, thereby reducing greenhouse gas emissions in the process, and promoting sustainable construction practices. [2] Reusing the construction waste or the debris of a redevelopment project can be a great opportunity for such revival projects to be cost effective. (H.Y Zhao, 2016) States that brick and stone waste from construction sites can be constructed into a beautiful pattern of gravel pavement in a garden. A variety of re-use methods can be created through transformation of building material also. For example, brick slag is a very good mineral material, and according to specific methods, sintering bricks can be processed into decorative particles to cover the exposed planting pits. Excavated soil from construction sites can be conditioned and used in gardening and landscape applications. Lighter mixed woods can be crushed and used as mulch in landscaping. [15]

Hence, for material conservation the salvaged material can give affordability to such revival model. The construction waste from one site can be salvaged and reused in the recreational garden; this will also result into a little less reduction in landfill and waste management.

\subsubsection{Water conservation}

The landscape can be leveraged to manage water. Water can be tapped through storm water management. Mumbai receives average annual rainfall of $2422 \mathrm{~mm}$ as per Indian Meteorological Department (IMD) which can be utilized to harvest roof top and surface run-off for watering the landscapes in the recreational garden. In the context of managing storm water, bio swales, bio-retention ponds, ring wells and permeable pavements are a few key examples of local green infrastructure which help turn hard asphalt surfaces into softscapes [1]. The recreational garden can be used as a sponge for ground water recharge in a development.

Another sustainable way of managing water is the grey water management. As per the research of Gawandalkar, phytorid systems can be the best green technology to satisfy water demand of small scale gardens. An affordable housing development can use the 'model for utilization of recycled waster' in gardens where the grey water from a residential building undergoes screening \& sedimentation and enters the phytorid system set-up. The treated water is collected to water the garden. [7]

\subsubsection{Sustainable Landscape Practices}

Sustainable landscapes are responsive to the environment, re-generative, and use native trees and plants for greater survival and climatic resilience. As per American Society of Landscape Architecture, Sustainable landscapes help to sequester carbon, clean the air and water, increase energy efficiency, restore habitats, and create value through significant economic, social and, environmental benefits.[1] According to 'A Manual for Urban Greening in MMR, promoting the concept of cluster plantation with indigenous plant species in recreational spaces and gardens may prove beneficial in maintaining the ecological balance of the environment, aid in conservation of native biodiversity, and primarily less maintenance as compared to the exotic landscape plantation. [8]

\section{Case study of Recreational Space Revival}

Kaifi Azmi Udyan, Juhu, Mumbai is a neighborhood park which was lying neglected for several years. It had turned into a dumpyard. The local residents' association, including Architect P. K. Das, with the active support of Ms Shabana Azmi (MP), decided to revive the 7000 sq.mtrs park for recreational use. The space was particularly developed for locals as a space for walking and jogging. The landscape in the park consists of aromatic and medicinal herbs and flowering plants. The existing mangrove along the periphery has also been revived. A demonstration of solid waste composting and recycling is also available in the park for the visitor which is then used as manure for the landscape [14]. Conceptualization of design was jointly done by $\mathrm{Ar}$. P.K.Das, environmental journalist Darryl D'Monte and environmentalist Vivek Kulkarni.

\section{Conclusion}

To provide a better quality of life along with the affordability of houses should be an aim of the competent authority. Though scarcity of land is an astounding issue in Mumbai, but a better living environment with facilities to recreate provides health, peace and prosperity to the city dwellers. Cost and maintenance are the prime parameters in the affordable housing development hence a resilient and cost effective model for recreational garden should be researched to fill the gap.

The salvaged materials from the construction site to build a recreational garden will decrease the capital cost of the model. Providing on-site waste-water and solid waste management for landscaping will help in decrease the operational cost of the model.

Native cluster plantation will help to promote biodiversity and will optimize water management for the Recreational Ground (RG). Also the cluster plantation with indigenous trees, shrubs, herbs and ground cover will make the landscape self-sufficient. 


\section{International Journal of Science and Research (IJSR) \\ ISSN (Online): 2319-7064}

Index Copernicus Value (2015): 78.96 | Impact Factor (2015): 6.391

\section{References}

[1] ASLA. (2016). American Society of Landscape Architects. Retrieved 2017 3-April from www.asla.org: https://www.asla.org/sustainablelandscapes/Vid_Water Management.html

[2] ASLA. (2017). American Society of Landscape Architects. Retrieved 2017 4-April from www.asla.org: https://www.asla.org/sustainablelandscapes/Vid_Parks.h tml

[3] Cecil C. Konijnendijk, M. A. (2013). Benefits of Urban Parks. Copenhagen \& Alnarp: IFPRA.

[4] Das, P. Open Mumbai. The National Gallery of Modern Art, Mumbai.

[5] Das, P. (2015). Placing Landscapes in Public Domain. IOSLA conference. Pune.

[6] Deborah Cohen, В. Н. (2016 йил 30-may). Retrieved 2017 9-april from RAND.org: https://www.rand.org/pubs/external_publications/EP664 93.html

[7] Gawandalkar, J. (2015 June). Graywater . M.Arch dissertation. Mumbai, India: RSIEA.

[8] Grassroots. (n.a). A Manual For Urban Greening in MMR. Mumbai: MMR-Environment Improvement Society.

[9] H.Y Zhao, Y. G. (2016). The comprehensive utilization of building material waste based on green building system. Advances in Civil, Architectural, Structural and Constructional Engineering , 149-152.

[10] Kakkar, A. (2014). Socio-economic Benefits of Open Spaces: Towards Sustainable Housing. International Journal of Environmental Research and Development, Vol-4,N0.1 , 17-20.

[11] Kent, F. (2015 5-october ). Project for public spaces. Retrieved 2017 9-april from http://www.pps.org: http://www.pps.org/blog/public-spaces-celebratingworld-habitat-day-2015/

[12] MEA. (2005). Millennium Ecosystem Assessment. New York: United Nations.

[13](1999). Merriam-Webster's collegiate dictionary (10th ed.). Springfield: MA: Merriam-Webster Incorporated.

[14] P.K.Das \& associates. (2015). Retrieved 2017 3-April from P.K.Das \& associates website: http://www.pkdas.com/kaifi-azmi-udyan-juhu-mumbaiproject-124-3-46.php

[15]Patrick X.Y Zou, D. R. (2014). Building and construction waste materials:Opportunities and strategies for the Capital region. Canberra, Australia: Canberra Business Chamber.

[16]RAND. (2006). Park use and Physical Activity in a Sample of Public park in the City of Los Angeles. Santa Monica, CA: RAND Corporation.

[17] Standardised Development Control And Promotion Regulations For Municipal Corporation in Maharashtra. (2013, November 13). Retrieved April 4, 2017, from mhada.maharashtra.gov.in: https://mhada.maharashtra.gov.in/sites/default/files/DC R_4.pdf

[18](2016). The Cities of the World 2016-Data Booklet. United Nations,Department of Economic and Social Affairs, Population Division.

[19] Urban Greening Guidelines, MoUD. (2014 February). Retrieved
9-April

Volume 6 Issue 7, July 2017 www.indiaenvironmentportal.org:

http://www.indiaenvironmentportal.org.in/files/file/urba n\%20green\%20guidelines\%202014.pdf 